Article

\title{
Determination of the Chemical Structures of Tandyukisins B-D, Isolated from a Marine Sponge-Derived Fungus
}

\section{Takeshi Yamada *, Yoshihide Umebayashi, Maiko Kawashima, Yuma Sugiura, Takashi Kikuchi and Reiko Tanaka}

Osaka University of Pharmaceutical Sciences, 4-20-1, Nasahara, Takatsuki, Osaka 569-1094, Japan; E-Mails: j.apricot_woods-0621@docomo.ne.jp (Y.U.); when-you.with-upon.a-star@disney.ne.jp (M.K.); ye9m13bxwt2kkbzpyxyf@docomo.ne.jp (Y.S.); t.kikuchi@gly.oups.ac.jp (T.K.); tanakar@gly.oups.ac.jp (R.T.)

* Author to whom correspondence should be addressed; E-Mail: yamada@gly.oups.ac.jp;

Tel.: +81-72-690-1085; Fax: +81-72-690-1084.

Academic Editor: Vassilios Roussis

Received: 18 March 2015 / Accepted: 11 May 2015 / Published: 21 May 2015

\begin{abstract}
Tandyukisins B-D (1-3), novel decalin derivatives, have been isolated from a strain of Trichoderma harzianum OUPS-111D-4 originally derived from the marine sponge Halichondria okadai, and their structures have been elucidated on the basis of spectroscopic analyses using 1D and 2D NMR techniques. In addition, their chemical structures were established by chemical transformation. They exhibited weak cytotoxicity, but selective growth inhibition on panel screening using 39 human cancer cell lines.
\end{abstract}

Keywords: decalin; Trichoderma harzianum; marine microorganism; Halichondria okadai; cytotoxicity

\section{Introduction}

Marine microorganisms are potentially prolific sources of highly bioactive secondary metabolites that may offer useful leads in the development of new pharmaceutical agents. Based on the fact that some of the bioactive materials isolated from marine animals have been produced by associated microorganisms, we have focused our attention on new antitumor materials from microorganisms isolated from marine organisms [1-3]. We previously reported that a cytotoxic compound, tandyukisin A (4), a novel decalin derivative with an enolic $\beta$-ketoaldehyde, was isolated from a strain 
of Trichoderma harzianum OUPS-111D-4 originally derived from the marine sponge Halichondria okadai [4]. In addition, the known compounds trichoharzin (5) and eujavanicol A (6) were isolated together with it. Our continuing search for cytotoxic metabolites from this strain led to the isolation of three new decalin derivatives designated tandyukisins B-D (1-3) (Figure 1). These metabolites exhibited moderate cytotoxicity against a disease-oriented panel of 39 human cancer cell lines (HCC panel); however, they exhibited selective growth inhibition against central nervous system tumor cell lines. Trichoharzin [5] isolated from the same class of fungus, eujavanicols [6,7] from Eupenicillium javanicum, betaenones [8] from Phoma betae, stemphyloxin I [9] from Stemphylium botryosum, fusarielins [10] from Fusarium sp., pannomycin [11] from Geomyces pannorum, and australifungin [12] from Spopormiella australis have been reported as metabolites with a similar alkylated decalin skeleton. They have various bioactivities, such as antifungal, phytotoxic, and antibacterial; however, cytotoxicities of these compounds have not been reported to date. We describe herein the absolute stereostructures and biological activities of 1-3.

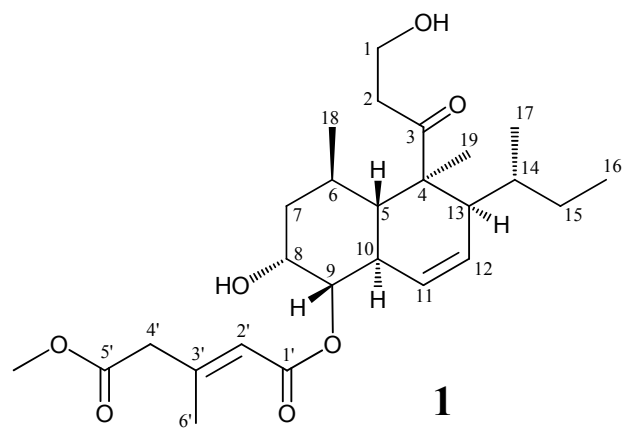<smiles>CCC(C)[C@H]1C=C[C@H]2C(OC(=O)C/C(C)=C\C(=O)O)C(O)CC(C)C2(C(=O)CCO)C1(C)C</smiles>

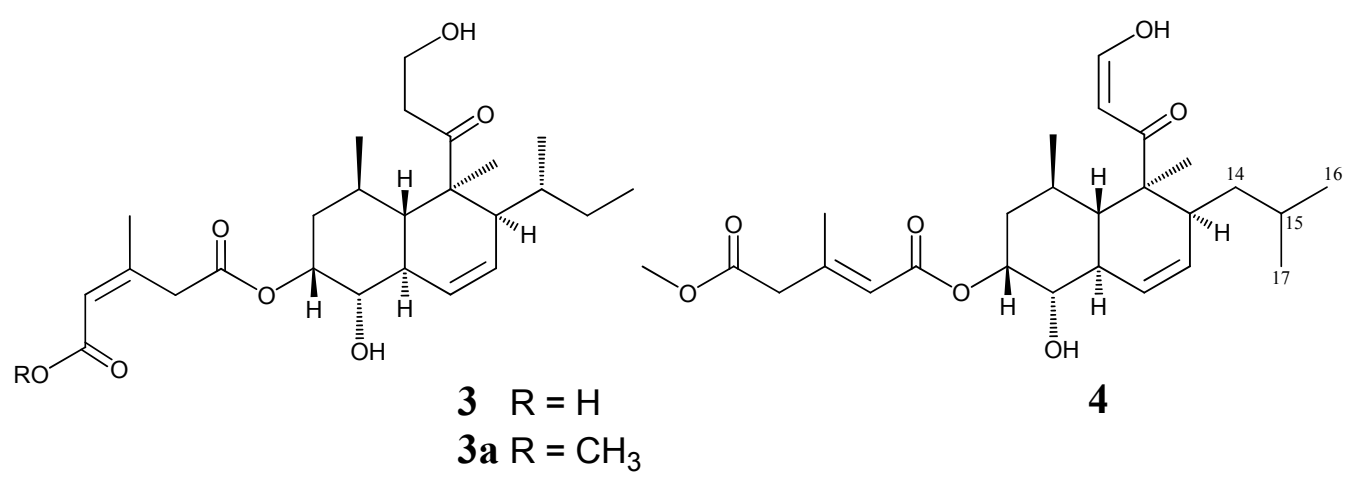<smiles>CCC(C)[C@H]1C=C[C@H]2[C@@H](O)[C@H](OC(=O)/C=C(\C)CC(=O)O)CC(C)C2(C(=O)CCO)C1(C)C</smiles>

5<smiles>CCC(C)[C@H]1C=C[C@H]2C(O)C(O)CC(C)C2(C(=O)CCO)C1C</smiles>

6

Figure 1. Structures of metabolites 1-6. 


\section{Results and Discussion}

T. harzianum, a microorganism from $H$. okadai, was cultured at $27{ }^{\circ} \mathrm{C}$ for six weeks in a medium (70 L) containing $1 \%$ glucose, $1 \%$ malt extract and $0.05 \%$ peptone in artificial seawater adjusted to $\mathrm{pH}$ 7.5. After incubation, the EtOAc extract of the culture filtrate was purified employing a stepwise combination of silica gel column chromatography and reverse phase HPLC to afford tandyukisins B (1) (3.8 mg), C (2) (8.0 mg), and D (3) (12.0 mg) as pale yellow oil, respectively.

Tandyukisin B (1) had the molecular formula $\mathrm{C}_{26} \mathrm{H}_{40} \mathrm{O}_{4}$ as established from the $[\mathrm{M}+\mathrm{H}]^{+}$peak in HR FAB-MS. Its IR spectrum exhibited bands at 2958, 1715 and $1651 \mathrm{~cm}^{-1}$, characteristic of hydroxy groups, esters, and ketone. Close inspection of the ${ }^{1} \mathrm{H}$ and ${ }^{13} \mathrm{C}$ NMR spectra (Table 1) of 1 using DEPT and ${ }^{1} \mathrm{H}-{ }^{13} \mathrm{C}$ correlation spectroscopy (HSQC) revealed the presence of one primary methyl (C-16), two secondary methyls (C-17 and C-18), one tertiary methyl (C-19), one olefin methyl (C-6'), one methoxy group $\left(5^{\prime}-\mathrm{OCH}_{3}\right)$, five $\mathrm{sp}^{3}$-hybridized methylenes $\left(\mathrm{C}-1, \mathrm{C}-2, \mathrm{C}-7, \mathrm{C}-15\right.$, and $\left.\mathrm{C}-4^{\prime}\right)$ including one oxygen-bearing carbon $(\mathrm{C}-1)$, six oxygen-bearing $\mathrm{sp}^{3}$-methines $(\mathrm{C}-5, \mathrm{C}-6, \mathrm{C}-8$, C-9, $\mathrm{C}-10, \mathrm{C}-13$, and $\mathrm{C}-14)$ including two oxygen-bearing carbons (C-8 and $\mathrm{C}-9$ ), three $\mathrm{sp}^{2}$-methines (C-11, C-12, and C-2'), one quaternary $\mathrm{sp}^{3}$-carbon (C-4), one quaternary $\mathrm{sp}^{2}$-carbon $\left(\mathrm{C}-3^{\prime}\right)$, three carbonyl groups (C-3, C-1', and C-5') including two ester carbonyls (C-1' and C-5'). ${ }^{1} \mathrm{H}-{ }^{1} \mathrm{H}$ COSY analysis of 1 gave two partial structural units, as shown by the bold lines in Figure 2. The connection of these units with the remaining functional groups was determined on the basis of HMBC correlations, summarized in Figure 2, and the planar structure of $\mathbf{1}$ was elucidated, as shown in Figure 2. 1 was markedly different from $\mathbf{4}$ and $\mathbf{5}$ regarding the position of the esterified hydroxyl group. NOE correlation between $\mathrm{H}_{-} \mathbf{2}^{\prime}$ and $\mathrm{H}-4^{\prime}$ (Figure 3) revealed that $\mathbf{1}$ had the same geometrical configuration in the side chain as those of $\mathbf{4}$ and $\mathbf{5}$.

Table 1. ${ }^{1} \mathrm{H}$ and ${ }^{13} \mathrm{C}$ NMR Spectral Data for $\mathbf{1 , 2}, \mathbf{3}$, and $\mathbf{5}$.

\begin{tabular}{|c|c|c|c|c|c|c|c|c|c|c|c|c|c|c|c|c|}
\hline \multirow{3}{*}{$\begin{array}{c}\text { Position } \\
1 \mathrm{~A}\end{array}$} & \multicolumn{4}{|c|}{1} & \multicolumn{4}{|c|}{2} & \multicolumn{4}{|c|}{3} & \multicolumn{4}{|c|}{5} \\
\hline & \multicolumn{2}{|c|}{$\delta_{H_{H}}{ }^{a}$} & \multicolumn{2}{|c|}{$\boldsymbol{\delta}_{\mathbf{C}}$} & \multicolumn{2}{|c|}{$\delta_{\mathbf{H}}{ }^{a}$} & \multicolumn{2}{|c|}{$\delta_{C}$} & \multicolumn{2}{|c|}{$\delta_{H_{H}}{ }^{a}$} & \multicolumn{2}{|c|}{$\delta_{\mathbf{C}}$} & \multicolumn{2}{|c|}{$\delta_{H}{ }^{a}$} & \multicolumn{2}{|c|}{$\delta_{C}$} \\
\hline & 3.83 & ddd & 58.0 & (t) & 3.84 & ddd & 58.0 & $(\mathrm{t})$ & 3.83 & ddd & 58.0 & (t) & 3.84 & ddd & 58.0 & $(\mathrm{t})$ \\
\hline 1B & 3.89 & ddd & & & 3.90 & ddd & & & 3.91 & ddd & & & 3.90 & ddd & & \\
\hline $2 \mathrm{~A}$ & 2.66 & ddd & 41.2 & (t) & 2.67 & ddd & 41.1 & $(\mathrm{t})$ & 2.67 & ddd & 41.2 & $(\mathrm{t})$ & 2.67 & ddd & 41.2 & (t) \\
\hline $2 \mathrm{~B}$ & 2.87 & ddd & & & 2.85 & ddd & & & 2.86 & ddd & & & 2.86 & ddd & & \\
\hline 3 & & & 215.2 & (s) & & & 215.2 & (s) & & & 215.2 & (s) & & & 215.5 & (s) \\
\hline 4 & & & 52.5 & (s) & & & 52.5 & (s) & & & 52.5 & (s) & & & 52.5 & (s) \\
\hline 5 & 2.06 & $\mathrm{t}$ & 43.6 & (d) & 2.03 & $\mathrm{t}$ & 43.4 & (d) & 1.96 & $\mathrm{t}$ & 43.1 & (d) & 1.98 & $\mathrm{t}$ & 43.0 & (d) \\
\hline 6 & 1.82 & $\mathrm{~m}$ & 30.3 & (d) & 1.73 & $\mathrm{~m}$ & 30.5 & (d) & 1.59 & $\mathrm{~m}$ & 31.4 & (d) & 1.62 & $\mathrm{~m}$ & 31.5 & (d) \\
\hline $7 \alpha$ & 1.86 & $\mathrm{dt}$ & 40.7 & $(\mathrm{t})$ & 1.83 & $\mathrm{dt}$ & 40.1 & $(\mathrm{t})$ & 1.83 & $\mathrm{dt}$ & 39.1 & $(\mathrm{t})$ & 1.87 & $\mathrm{dt}$ & 39.0 & $(\mathrm{t})$ \\
\hline $7 \beta$ & 1.55 & td & & & 1.53 & $\mathrm{td}$ & & & 1.55 & $\mathrm{td}$ & & & 1.56 & $\mathrm{td}$ & & \\
\hline 8 & 4.13 & $\mathrm{q}$ & 67.6 & (d) & 4.28 & $\mathrm{q}$ & 66.7 & (d) & 5.26 & $\mathrm{q}$ & 73.3 & (d) & 5.26 & $\mathrm{q}$ & 72.7 & (d) \\
\hline 9 & 4.78 & $\mathrm{dd}$ & 77.4 & (d) & 4.55 & $\mathrm{dd}$ & 78.8 & (d) & 3.48 & $\mathrm{dd}$ & 74.2 & (d) & 3.56 & $\mathrm{dd}$ & 74.4 & (d) \\
\hline 10 & 2.46 & tdd & 36.2 & (d) & 2.47 & brt & 36.0 & (d) & 2.08 & tdd & 40.4 & (d) & 2.12 & tdd & 40.3 & (d) \\
\hline 11 & 5.62 & brd & 125.0 & (d) & 5.69 & drd & 125.1 & (d) & 6.06 & $\mathrm{dt}$ & 125.9 & (d) & 6.04 & brd & 125.8 & (d) \\
\hline 12 & 5.74 & ddd & 124.5 & (d) & 5.67 & $\mathrm{dd}$ & 124.5 & (d) & 5.69 & ddd & 123.7 & (d) & 5.70 & ddd & 123.8 & (d) \\
\hline 13 & 1.94 & $\mathrm{~m}$ & 52.4 & (d) & 1.94 & $\mathrm{~m}$ & 52.3 & (d) & 1.94 & $\mathrm{~m}$ & 52.4 & (d) & 1.94 & $\mathrm{~m}$ & 52.4 & (d) \\
\hline
\end{tabular}


Table 1. Cont.

\begin{tabular}{|c|c|c|c|c|c|c|c|c|c|c|c|c|c|c|c|c|}
\hline 14 & 1.12 & $\mathrm{~m}$ & 37.2 & (d) & 1.12 & $\mathrm{~m}$ & 37.2 & (d) & 1.12 & $\mathrm{~m}$ & 37.2 & (d) & 1.12 & $\mathrm{~m}$ & 37.2 & (d) \\
\hline $15 \mathrm{~A}$ & 0.74 & $\mathrm{~m}$ & 24.4 & $(\mathrm{t})$ & 0.72 & $\mathrm{~m}$ & 24.5 & $(\mathrm{t})$ & 0.74 & $\mathrm{~m}$ & 24.4 & $(\mathrm{t})$ & 0.74 & $\mathrm{~m}$ & 24.4 & (t) \\
\hline $15 \mathrm{~B}$ & 1.50 & $\mathrm{~m}$ & & & 1.47 & $\mathrm{~m}$ & & & 1.47 & $\mathrm{~m}$ & & & 1.47 & $\mathrm{~m}$ & & \\
\hline 16 & 0.76 & $\mathrm{t}$ & 12.5 & (q) & 0.75 & $\mathrm{t}$ & 12.5 & (q) & 0.76 & $\mathrm{t}$ & 12.5 & (q) & 0.76 & $\mathrm{t}$ & 12.5 & (q) \\
\hline 17 & 0.92 & $\mathrm{~d}$ & 19.1 & (q) & 0.92 & $\mathrm{~d}$ & 19.2 & (q) & 0.93 & $\mathrm{~d}$ & 19.2 & (q) & 0.93 & $\mathrm{~d}$ & 19.3 & (q) \\
\hline 18 & 0.60 & $\mathrm{~d}$ & 22.3 & (q) & 0.59 & $\mathrm{~d}$ & 22.3 & (q) & 0.59 & $\mathrm{~d}$ & 22.3 & (q) & 0.59 & $\mathrm{~d}$ & 22.2 & (q) \\
\hline 19 & 1.26 & $\mathrm{~s}$ & 19.4 & (q) & 1.26 & $\mathrm{~s}$ & 19.3 & (q) & 1.25 & $\mathrm{~s}$ & 19.3 & (q) & 1.26 & $\mathrm{~s}$ & 19.4 & (q) \\
\hline $1^{\prime}$ & & & 164.9 & (s) & & & 170.0 & (s) & & & 168.9 & (s) & & & 166.2 & (s) \\
\hline $2^{\prime} \mathrm{A}$ & 5.88 & $\mathrm{~s}$ & 118.9 & (d) & 3.29 & $\mathrm{~d}$ & 39.7 & $(\mathrm{t})$ & 5.92 & $\mathrm{~s}$ & 118.1 & (d) & 5.88 & $\mathrm{~s}$ & 119.7 & (d) \\
\hline $2^{\prime} \mathrm{B}$ & & & & & 3.77 & $d$ & & & & & & & & & & \\
\hline $3^{\prime}$ & & & 152.0 & (s) & & & 153.4 & (s) & & & 153.9 & (s) & & & 151.7 & (s) \\
\hline $4^{\prime} \mathrm{A}$ & 3.19 & $\mathrm{~s}$ & 45.7 & $(t)$ & 5.94 & $\mathrm{~s}$ & 118.5 & (d) & 3.54 & $d$ & 39.6 & $(\mathrm{t})$ & 3.19 & $\mathrm{~s}$ & 45.4 & $(\mathrm{t})$ \\
\hline $4^{\prime} \mathrm{B}$ & & & & & & & & & 3.73 & $\mathrm{~d}$ & & & & & & \\
\hline $5^{\prime}$ & & & 170.2 & (s) & & & 168.9 & (s) & & & 169.8 & (s) & & & 173.5 & (s) \\
\hline $6^{\prime}$ & 2.27 & $\mathrm{~s}$ & 19.2 & (q) & 2.08 & $\mathrm{~s}$ & 27.4 & (q) & 2.05 & $\mathrm{~s}$ & 26.9 & (q) & 2.27 & $\mathrm{~s}$ & 19.1 & (q) \\
\hline $5^{\prime}-\mathrm{OCH}_{3}$ & 3.73 & $\mathrm{~s}$ & 52.2 & (q) & & & & & & & & & & & & \\
\hline
\end{tabular}

${ }^{\text {a } 1} \mathrm{H}$ chemical shift values ( $\mathrm{d}$ ppm from SiMe4) followed by multiplicity.

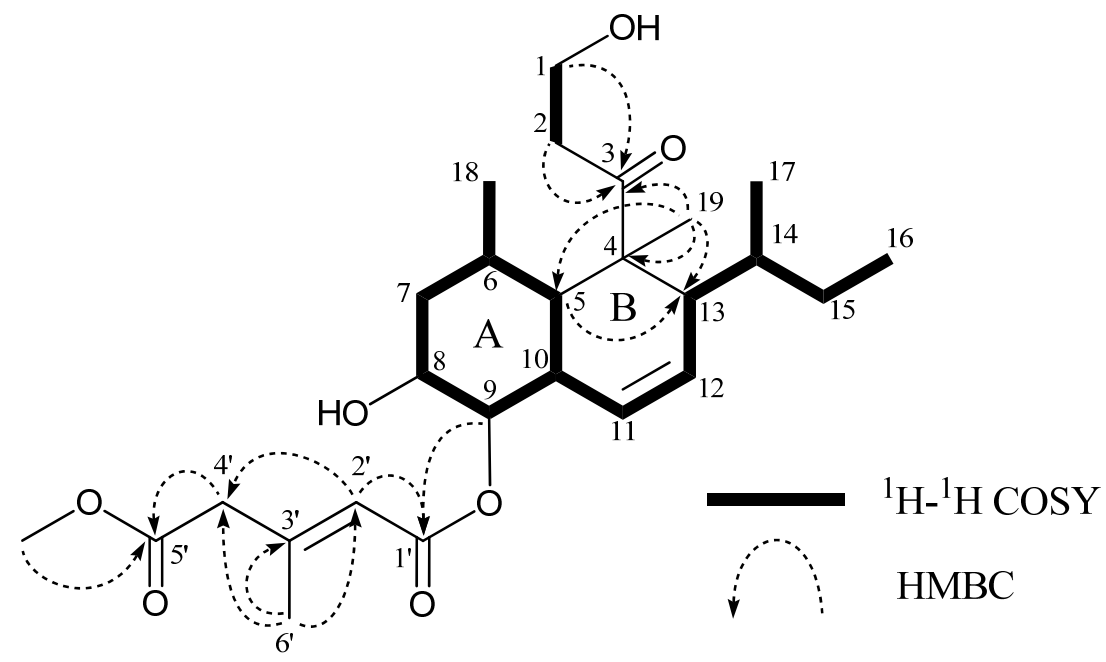

Figure 2. Selected ${ }^{1} \mathrm{H}-{ }^{1} \mathrm{H}$ COSY and HMBC correlations of 1.

The relative stereochemistry of $\mathbf{1}$ was deduced from NOESY experiments (Figure 3). NOE correlations $(\mathrm{H}-5 / \mathrm{H}-7 \beta, \mathrm{H}-5 / \mathrm{H}-9, \mathrm{H}-9 / \mathrm{H}-7 \beta$, and $\mathrm{H}-6 / \mathrm{H}-10)$ suggested that the A ring existed in a chair conformation with $\mathrm{H}-5, \mathrm{H}-7 \beta$, and $\mathrm{H}-9$ in coaxial arrangements. This evidence and the vicinal coupling constants $\left(J_{7 \alpha, 8}=J_{7 \beta, 8}=J_{9,8}=2.5 \mathrm{~Hz}\right)$ showed that the esterified side chain at C-9 was oriented cis to $8-\mathrm{OH}$ in an equatorial arrangement. NOE correlations $(\mathrm{H}-10 / \mathrm{H}-19, \mathrm{H}-5 / \mathrm{H}-15$, and $\mathrm{H}-2 \mathrm{~B} / \mathrm{H}-18)$ in the $\mathrm{B}$ ring revealed that it existed in a half chair conformation, and the sec-butyl group was oriented trans to $\mathrm{C}-19$. For the stereochemistry at $\mathrm{C}-14$ in the sec-butyl group, the observed NOE correlations in $\mathbf{1}$ were equal to those of 5 [5], which revealed the stereochemistry at $\mathrm{C}-14$, i.e., NOE correlations (H-5/H-15B, H-2A/H-13, H-2A/H-14, H-13/H-17, H-12/H-17, and $\mathrm{H}-12 / \mathrm{H}-16$ ) suggested that the rotation of the sec-butyl group in its pseudo-axial arrangement was limited; therefore, the relative configuration for C-14 was deduced as $S^{*}$ (Figure 3). For the determination of the absolute 
stereostructure of $\mathbf{1}$, alkali-hydrolysis was carried out. The treatment of $\mathbf{1}$ with $\mathrm{NaOH}$ in aqueous $\mathrm{MeOH}$ gave a hydrolysis product, which was identical to 6 in terms of ${ }^{1} \mathrm{H}$ NMR data and the specific rotation (the hydrolysis product; $[\alpha]_{\mathrm{D}}+46.5,6$ : $[\alpha]_{\mathrm{D}}+41.1$ ). This evidence led to the absolute stereostructure of $\mathbf{1}$, and confirmed the stereochemistry at C-14 derived from NOE correlations.

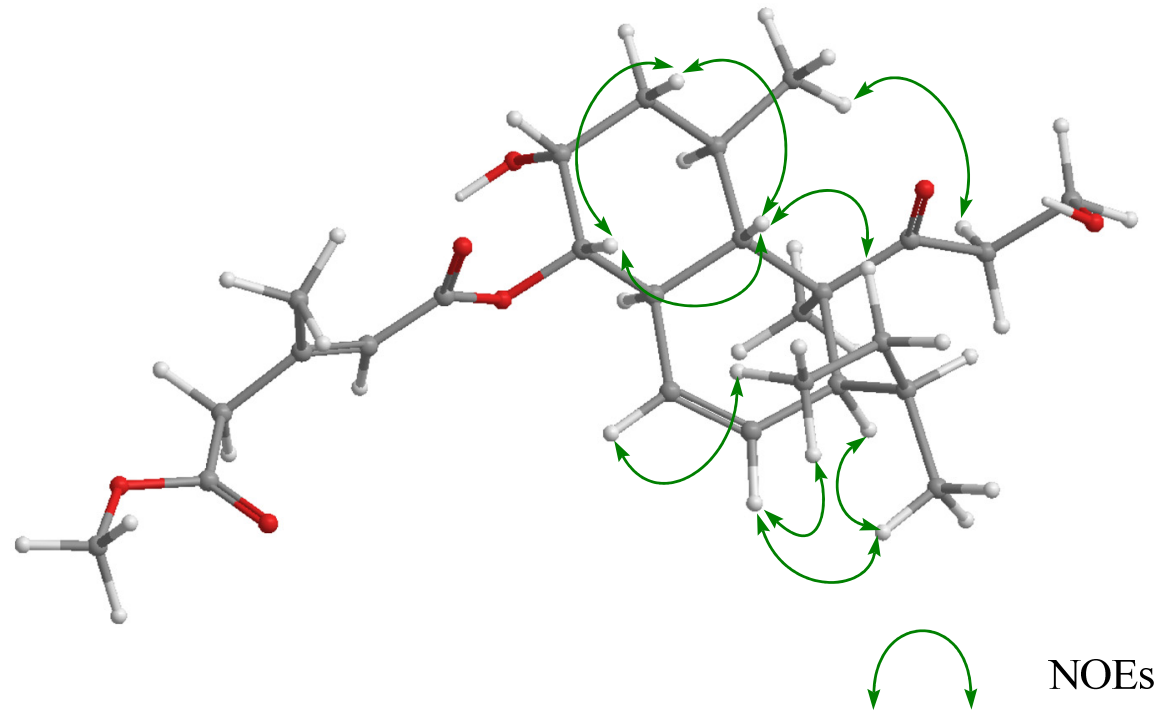

Figure 3. Key NOESY correlations of 1.

Tandyukisin $\mathrm{C}$ (2) was assigned the same molecular formula $\mathrm{C}_{25} \mathrm{H}_{38} \mathrm{O}_{7}$ as 5 based on HR FAB-MS data. The general features of its UV, IR, and NMR spectra (Table 1) closely resembled those of 5 except for some of the ${ }^{1} \mathrm{H}$ and ${ }^{13} \mathrm{C}$ NMR signals (H-8 $\left(\Delta \delta_{\mathrm{H}} 0.98\right), \mathrm{H}-9\left(\Delta \delta_{\mathrm{H}} 1.00\right), \mathrm{H}-10\left(\Delta \delta_{\mathrm{H}} 0.35\right)$, $\mathrm{H}-11\left(\Delta \delta_{\mathrm{H}} 0.35\right), \mathrm{C}-8\left(\Delta \delta_{\mathrm{C}} 6.0\right), \mathrm{C}-9\left(\Delta \delta_{\mathrm{C}} 4.4\right)$, and C-10 $\left.\left(\Delta \delta_{\mathrm{C}} 4.2\right)\right)$. At this point, we thought that 2 also had an esterified side chain at C-9 as 1. However, additional analysis of the NMR chemical shifts at the side chain of $\mathbf{2}$ showed marked differences from those of $\mathbf{5}$, and suggested that its structure must be markedly different. ${ }^{1} \mathrm{H}-{ }^{1} \mathrm{H}$ COSY and $\mathrm{HMBC}$ experiments led to the elucidation of the planar structure of 2, which was the same as those of $\mathbf{1}$ and $\mathbf{5}$ except for the esterified side chain C-1'-C-6'. In the HMBC experiments, the correlations (H-9/C-1', H-2'/C-1', H-2'/C-4', H-4'/C-5', H-6'/C-2', $\mathrm{H}-6^{\prime} / \mathrm{C}-3^{\prime}$, and $\left.\mathrm{H}-6^{\prime} / \mathrm{C}-4^{\prime}\right)$ demonstrated that another carboxylic acid in the side chain, which was dicarboxylic acid originally, condensed to the hydroxyl group at C-9. In addition, a detailed examination of NOESY led to the finding that the geometrical configuration in the side chain was $Z$, while those of 1 and 5 were E, i.e., the NOE correlations between H-6' and H-4' in $\mathbf{2}$ were observed instead of those between $\mathrm{H}-2^{\prime}$ and $\mathrm{H}-4^{\prime}$ in $\mathbf{1}$ and $\mathbf{5}$. For the stereochemistry of $\mathbf{2}$, all NOE correlations except for the above were identical to those of $\mathbf{1}$ and 5. In addition, alkali-hydrolysis in the same manner as described above gave a hydrolysis product, which was identical to $\mathbf{6}$ in terms of spectral data, including the specific rotation $\left([\alpha]_{\mathrm{D}}+42.7\right)$. The above evidence established the absolute stereostructure of $\mathbf{2}$ as shown in Figure 1.

Tandyukisin D (3) was assigned the same molecular formula $\mathrm{C}_{25} \mathrm{H}_{38} \mathrm{O}_{7}$ as $\mathbf{2}$, based on deductions made from HR FAB-MS data. Its spectral data were similar to those of the related compounds 1, 2, 4, and $\mathbf{5}$ isolated to date. Especially, there were marked similarities between $\mathbf{3}$ and $\mathbf{5}$ except for the NMR signals of the side chain. On the other hand, the same NMR chemical shifts for the side chain of $\mathbf{3}$ 
corresponded exactly to those of $\mathbf{2}$ (Table 1). Based on the ${ }^{1} \mathrm{H}-{ }^{1} \mathrm{H}$ COSY and HMBC correlations for $\mathbf{3}$, the planar structure esterified at C-8 could be deduced together with the ${ }^{1} \mathrm{H}$ NMR chemical shift at $\mathrm{H}-8$ ( $\delta_{\mathrm{H}}$ 5.26); however, an HMBC correlation from $\mathrm{H}-8$ to $\mathrm{C}-\mathrm{1}^{\prime}$ was not observed. In order to examine which of the two carboxy groups in the side chain dicarboxylic acid condensed to 8-OH, we performed methylation of $\mathbf{3}$. The addition of trimethylsilyldiazomethane to $\mathbf{3}$ gave methyl ester derivative $\mathbf{3 a}$. The HMBC correlation from the methyl group imported newly in 3a assigned a carboxy group as C-5', and then another one was assigned as $\mathrm{C}-1^{\prime}$ condensed to 8-OH. Consequently, the assignment of the NMR signals for the side chain was completed. In the NOESY experiment for $\mathbf{3}$, the correlations between H-6' and H-4' showed that the geometry in the side chain was $Z$, as that of 2 . A detailed examination of NOESY revealed the relative configuration of the chiral centers, except for the above, which were identical to those of $\mathbf{1}, \mathbf{2}$, and $\mathbf{5}$. The absolute stereostructure of $\mathbf{3}$ was confirmed by alkali-hydrolysis. As expected, the hydrolysis product was identical to $\mathbf{6}$ in terms of spectral data, including the specific rotation $\left([\alpha]_{\mathrm{D}}+43.8\right)$.

As primary screening for antitumor activity, cancer cell growth inhibitory properties of tandyukisins B-D (1-3) were examined using a disease-oriented panel of 39 human cell lines (HCC panel) $[13,14]$. The effective concentration (MG-MID), delta value, and range value for $\mathbf{1}$ did not show significant cytotoxic activity (effective value: MG-MID $<-5$, delta $\geq 0.5$, and range $\geq 1.0$ ) (Table 2 ). However, 1-3 exhibited slightly selective growth inhibition against the central nervous system cancer SNB-75 cell line in the HCC panel (log GI50 values: $-4.36,-4.56$, and -4.54 , respectively).

Table 2. Cytotoxity of $\mathbf{1}-\mathbf{3}$ against a panel of 39 human cancer cell lines.

\begin{tabular}{cccc}
\hline Sample & $\mathbf{1}$ & $\mathbf{2}$ & $\mathbf{3}$ \\
\hline MG-MID $^{\mathrm{a}}$ & -4.01 & -4.04 & -4.01 \\
Delta $^{\mathrm{b}}$ & 0.35 & 0.52 & 0.53 \\
Range $^{\mathrm{c}}$ & 0.36 & 0.56 & 0.54 \\
\hline
\end{tabular}

${ }^{\text {a }}$ Mean value of $\log \mathrm{GI}_{50}$ over all cell lines tested; ${ }^{\mathrm{b}}$ The difference in $\log \mathrm{GI}_{50}$ value of the most sensitive cell and MG-MID value; ${ }^{c}$ The difference in $\log \mathrm{GI}_{50}$ value of the most sensitive cell and the least sensitive cell.

\section{Experimental Section}

\subsection{General Experimental Procedures}

UV spectra were recorded on a Shimadzu spectro-photometer U-2000 and IR spectra on a JASCO FT/IR-680 Plus. NMR spectra were recorded at $27{ }^{\circ} \mathrm{C}$ on Agilent-NMR-vnmrs600 with tetramethylsilane (TMS) as an internal reference. Mass spectra were determined using a Hitachi $\mathrm{M}-4000 \mathrm{H}$ mass spectrometer. ORD were recorded on a JASCO J-820 polarimeters. Liquid chromatography over silica gel (mesh 230-400) was performed in a medium pressure. HPLC was run on a JASCO PU-1586 equipped with a differential refractometer (RI-1531) and Cosmosil Packed Column 5C18-MSII $(25 \mathrm{~cm} \times 20 \mathrm{~mm}$ i.d.). Analytical TLC was performed on precoated Merck aluminum sheets (DC-Alufolien Kieselgel $60 \mathrm{~F} 254,0.2 \mathrm{~mm}$ ) with the solvent system $\mathrm{CH}_{2} \mathrm{Cl}_{2}-\mathrm{MeOH}$ (19:1), and compounds were viewed under UV lamp and sprayed with $10 \% \mathrm{H}_{2} \mathrm{SO}_{4}$ followed by heating. 


\subsection{Fungal Material}

The fungus Trichoderma harzianum was isolated from a piece of inner tissue of the marine sponge Halichondria okadai collected at collected in Osaka bay, Japan in October 2008. The fungal strain was identified by Techno Suruga Laboratory Co., Ltd. (Shizuoka, Japan). The sponge was wiped with EtOH and its snip applied to the surface of nutrient agar layered in a Petri dish. Serial transfers of one of the resulting colonies provided a pure strain of T. harzianum.

\subsection{Culturing and Isolation of Metabolites}

The fungal strain was cultured at $27{ }^{\circ} \mathrm{C}$ for six weeks in a liquid medium $(70 \mathrm{~L})$ containing $1 \%$ glucose, $1 \%$ malt extract and $0.05 \%$ pepton in artificial seawater adjusted to $\mathrm{pH} 7.5$. The culture filtrate was extracted thrice with EtOAc. The combined extracts were evaporated in vacuo to afford a mixture of crude metabolites (17.2 g). The EtOAc extract was chromatographed on a silica gel column with a $\mathrm{CHCl}_{3}-\mathrm{MeOH}$ gradient as the eluent. The $\mathrm{MeOH}-\mathrm{CHCl}_{3}$ (1:99) eluate (1.6 g) was repeated a silica gel column with a $n$-hexane-EtOAc gradient as the eluent. The $n$-hexane-EtOAc (30:70) eluate (323.2 mg) was purified by HPLC using $\mathrm{MeOH}-\mathrm{H}_{2} \mathrm{O}(73: 27)$ as the eluent to afford 1 (3.8 $\left.\mathrm{mg}\right)$. In the second silica gel column chromatography, another $n$-hexane-EtOAc (30:70) eluate $(292.6 \mathrm{mg})$ was purified by HPLC using $\mathrm{MeOH}-\mathrm{H}_{2} \mathrm{O}$ (70:30) as the eluent to afford 2 (8.0 mg) and 3 (12.0 mg).

Tandyukisin B (1) Pale yellow oil; $[\alpha]_{\mathrm{D}}^{22}-27.9$ (c 0.08, EtOH); UV $\lambda \max (\mathrm{EtOH}) / \mathrm{nm}: 341(\log \varepsilon$ 2.14). IR (neat) $v_{\max } / \mathrm{cm}^{-1}: 2958,1715,1651$. FABMS $\mathrm{m} / z$ (rel. int.): 487 ([M $\left.\left.+\mathrm{Na}\right]^{+}, 11.3 \%\right) 465$ $\left([\mathrm{M}+\mathrm{H}]^{+}, 35.1 \%\right), 447\left([\mathrm{M}-\mathrm{OH}]^{+}, 5.3 \%\right), 307(77.1 \%), 289$ (24.4\%), 159 (26.8\%), 141 (100\%). HRFABMS $m / z$ 465.2859 $[\mathrm{M}+\mathrm{H}]^{+}$(calcd for $\mathrm{C}_{26} \mathrm{H}_{41} \mathrm{O}_{7}: 465.2852$ ). ${ }^{1} \mathrm{H}$ and ${ }^{13} \mathrm{C}$ NMR data are listed in Table 1 and Table S1 (SI).

Tandyukisin C (2) Pale yellow oil; $[\alpha]_{\mathrm{D}^{22}}^{22} 16.2$ (c 0.10, EtOH); UV $\lambda_{\max }(\mathrm{EtOH}) / \mathrm{nm}: 341(\log \varepsilon$ 2.35). IR (neat) $v_{\max } / \mathrm{cm}^{-1}: 2960,1698,1652$. FABMS $\mathrm{m} / z$ (rel. int.): $473\left([\mathrm{M}+\mathrm{Na}]^{+}, 100 \%\right) 451$ $\left([\mathrm{M}+\mathrm{H}]^{+}, 28.2 \%\right), 433\left([\mathrm{M}-\mathrm{OH}]^{+}, 32.9 \%\right), 307(77.1 \%), 289(60.2 \%), 159(64.1 \%), 127(77.9 \%)$. HRFABMS $m / z 451.2703[\mathrm{M}+\mathrm{H}]^{+}$(calcd for $\left.\mathrm{C}_{25} \mathrm{H}_{39} \mathrm{O}_{7}: 451.2696\right) .{ }^{1} \mathrm{H}$ and ${ }^{13} \mathrm{C}$ NMR data are listed in Table 1 and Table S2 (SI).

Tandyukisin D (3) Pale yellow oil; $[\alpha]_{\mathrm{D}^{22}}+32.2$ (c 0.09, EtOH); UV $\lambda_{\max }(\mathrm{EtOH}) / \mathrm{nm}: 341(\log \varepsilon$ 2.72). IR (neat) $v_{\max } / \mathrm{cm}^{-1}: 2926,1698$. FABMS $m / z$ (rel. int.): $473\left([\mathrm{M}+\mathrm{Na}]^{+}, 7.8 \%\right) 451\left([\mathrm{M}+\mathrm{H}]^{+}\right.$, 10.7\%), $433\left([\mathrm{M}-\mathrm{OH}]^{+}, 13.4 \%\right), 307$ (16.6\%), 289 (15.9\%), 159 (20.7\%), 154 (100\%). HRFABMS $m / z 451.2705[\mathrm{M}+\mathrm{H}]^{+}$(calcd for $\left.\mathrm{C}_{25} \mathrm{H}_{39} \mathrm{O}_{7}: 451.2696\right) .{ }^{1} \mathrm{H}$ and ${ }^{13} \mathrm{C}$ NMR data are listed in Table 1 and Table S3 (SI).

\subsection{Chemical Transformation}

\subsubsection{The Hydrolysis of $\mathbf{1}-\mathbf{3}$}

To a solution of $1(2.2 \mathrm{mg})$ in $\mathrm{MeOH}(0.5 \mathrm{~mL}) 0.1 \mathrm{M} \mathrm{NaOH}$ aq. was added, and the reaction mixture was stirred at room temperature for $30 \mathrm{~min}$. The reaction mixture extracted with diethyl ether thrice, and the organic layer was evaporated under reduced pressure. The residue was purified by HPLC using $\mathrm{MeOH}-\mathrm{H}_{2} \mathrm{O}(70: 30)$ as the eluent to afford $6(1.0 \mathrm{mg})$. Using the same procedure, 
$2(8.1 \mathrm{mg})$ and $3(2.9 \mathrm{mg})$ were treated with $0.01 \mathrm{M} \mathrm{NaOH}$ aq. and purified by HPLC to afford $6(1.2 \mathrm{mg}$ and $0.9 \mathrm{mg})$, respectively.

\subsubsection{The Methylation of 3}

Trimethylsilyldiazomethane $(2 \mathrm{~mL})$ was added to a solution of $3(1.4 \mathrm{mg})$ in $\mathrm{CH}_{2} \mathrm{Cl}_{2}(0.5 \mathrm{~mL})$, and the reaction mixture was stirred at room temperature for $10 \mathrm{~h}$. The reaction mixture was evaporated under reduced pressure. The residue $(1.0 \mathrm{mg})$ was analyzed as $\mathbf{3 a}$ without purification.

3a Pale yellow oil; FABMS $m / z$ (rel. int.): $465\left([\mathrm{M}+\mathrm{H}]^{+}, 16.1 \%\right), 447\left([\mathrm{M}-\mathrm{OH}]^{+}, 23.0 \%\right)$, 141 (100\%). HRFABMS $m / z$ 465.2857 $[\mathrm{M}+\mathrm{H}]^{+}$(calcd for $\mathrm{C}_{20} \mathrm{H}_{41} \mathrm{O}_{7}: 465.2852$ ). ${ }^{1} \mathrm{H}$ and ${ }^{13} \mathrm{C}$ NMR data are listed in Table S4 (SI).

\section{Conclusions}

In this study, three novel decalin derivatives with an enolic $\beta$-ketoaldehyde, tandyukisins B-D (1-3), were isolated from a strain of Trichoderma harzianum derived from the marine sponge. The chemical structures of these compounds were elucidated by spectral analyses and chemical transformation.

In the screening to search for seeds of antitumor agents, these metabolites did not exhibit significant cytotoxic activity in the HCC panel. However, we suggest that the low-level selectivity demonstrated by them may aid in the development of a new chemotherapeutical agent.

\section{Acknowledgments}

We are grateful to M. Fujitake and K. Minoura of this university for MS and NMR measurements, respectively. This study was supported by a Grant-in-Aid for Scientific Research from the Japan Society for the Promotion of Science. Lastly, we thanks to Screening Committee of Anticancer Drugs supported by Grant-in-Aid for Scientific Research on Innovative Areas, Scientific Support Programs for Cancer Research, from The Ministry of Education, Culture, Sports, Science and Technology, Japan for the antitumor screening.

\section{Author Contributions}

Conceived and designed the experiments: Maiko Kawashima, Yoshihide Umebayashi, Reiko Tanaka, Takashi Kikuchi, and Takeshi Yamada; Performed the experiments: Maiko Kawashima, Yuma Sugiura, and Takeshi Yamada; Analyzed the data: Maiko Kawashima and Takeshi Yamada; Wrote the paper: Takeshi Yamada.

\section{Conflicts of Interest}

The authors declare no conflict of interest. 


\section{References}

1. Yamada, T.; Kitada, H.; Kajimoto, T.; Numata, A.; Tanaka, R. The relationship between the CD cotton effect and the absolute configuration of FD-838 and its seven stereoisomers. J. Org. Chem. 2010, 75, 4146-4153.

2. Yamada, T.; Kikuchi, T.; Tanaka, R.; Numata, A. Halichoblelides B and C, potent cytotoxic macrolides from a Streptomyces species separated from a marine fish. Tetrahedron Lett. 2012, 53, 2842-2846.

3. Nakanishi, K.; Doi, M.; Usami, Y.; Amagata, T.; Minoura, K.; Tanaka, R.; Numata, A.; Yamada, T. Anthcolorins A-F, novel cytotoxic metabolites from a sea urchin-derived Aspergillus versicolor. Tetrahedron 2013, 69, 4617-4623.

4. Yamada, T.; Mizutani, Y.; Umebayashi, Y.; Inno, N.; Kawashima, M.; Kikuchi, T.; Tanaka, R. Tandyukisin, a novel ketoaldehyde decalin derivative, produced by a marine sponge-derived Trichoderma harzianum. Tetrahedron Lett. 2014, 54, 662-664.

5. Kobayashi, M.; Uehara, H.; Matsunami, K.; Aoki, S.; Kitagawa, I. Trichoharzin, a new polyketide produced by the imperfect fungus Trichoderma harzianum separated from the marine sponge Micale cecilia. Tetrahedron Lett. 1993, 34, 7925-7928.

6. Nakadate, S.; Nozawa, K.; Horie, H.; Fujii, Y.; Nagai, M.; Hosoe, T.; Kawai, K.; Yaguchi, T.; Fukushima, K. Eujavanicols A-C, decalin derivatives from Eupenicillium javanicum. J. Nat. Prod. 2007, 70, 1510-1512.

7. Smetanina, O.F.; Kalinovskii, A.I.; Kicha, A.A.; Yurchenko, A.N.; Pivkin, M.V.; Kuznetsova, T.A. Dehydrodecalin derivative from marine isolate of the fungus Wardomyces inflatus. Chem. Nat. Compd. 2009, 45, 753-755.

8. Ichihara, A.; Oikawa, H.; Hayashi, K.; Sakamura, S. Structures of betaenones A and B, novel phytotoxins from Phoma betae Fr. J. Am. Chem. Soc. 1983, 105, 2907-2908.

9. Barash, I.; Pupkin, G.; Netzer, D.; Kashman, Y. A novel enolic $\beta$-ketoaldehyde phytotoxin by Stemphylium botryosum f. sp. Lycopersici. Partial chemical and biological characterization. Plant Physiol. 1982, 69, 23-27.

10. Kobayashi, H.; Sunaga, R.; Furihara, K.; Morisaki, N.; Iwasaki, S. Isolation and structures of an antifungal antibiotic, fusarietin $\mathrm{A}$, and related compounds produced by a Fusarium sp. J. Antibiot. 1995, 48, 42-52.

11. Parish, C.A.; Cruz, M.; Smith, S.K.; Zink, D.; Baxter, J.; Tucker-Samaras, S.; Collado, J.; Platas, G.; Bills, G.; Diez, M.T.; et al. Antisense-guided isolation and structure elucidation of pannomycin, a substituted cis-decalin from Geomyces pannorum. J. Nat. Prod. 2009, 72, 59-62.

12. Otto, D.H.; Gregory, L.; Helms Tracy, T.J.; Guy, H.H. Structure elucidation of australifungin, a potent inhibitor of sphinganine $N$-acyltransferase in sphingolipid biosynthesis from Sporormiella australis. J. Org. Chem. 1995, 60, 1772-1776.

13. Yamori, T.; Matsunaga, A.; Sato, S.; Yamazaki, K.; Komi, A.; Ishizu, K.; Mita, I.; Edatsugi, H.; Matsuba, Y.; Takezawa, K.; et al. Potent antitumor activity of MS-247, a novel DNA minor groove binder, evaluated by an in vitro and in vivo human cancer cell line panel. Cancer Res. 1999, 59, 4042-4049. 
14. Yamori, T. Panel of human cancer cell lines provides valuable database for drug discovery and bioinformatics. Cancer Chemother. Pharmacol. 2003, 52 (Suppl. 1), S74-S79.

(C) 2015 by the authors; licensee MDPI, Basel, Switzerland. This article is an open access article distributed under the terms and conditions of the Creative Commons Attribution license (http://creativecommons.org/licenses/by/4.0/). 